\title{
PHENOLIC COMPOUNDS, METHYLXANTHINES AND ANTIOXIDANT ACTIVITY IN COCOA MASS AND CHOCOLATES PRODUCED FROM “WITCH BROOM DISEASE” RESISTANT AND NON RESISTANT COCOA CULTIVARS
}

\author{
Compostos fenólicos, metilxantinas e atividade antioxidante em massa de cacau e chocolates \\ produzidos a partir de cultivares resistentes e não resistentes a "vassoura de bruxa"
}

\author{
Paula Bacelar Leite', Leonardo Fonseca Maciel ${ }^{1}$, Luiza Carolina França Opretzka', \\ Sergio Eduardo Soares ${ }^{2}$, Eliete da Silva Bispo ${ }^{3}$
}

\begin{abstract}
The "witch broom disease" caused by the fungus called Moniliophthora perniciosa is one of the most important cocoa diseases in Latin America, causing around $70 \%$ production reduction in the southern Bahia. In attempt to solve the problem, many cultivars resistant to the disease have been recommended to farmers. On the other hand, the chocolate flavour is composed by many compounds whose formation depends on the genetic background, environment where cocoa is grown and processing operations. Therefore, this work aimed at determining the monomeric phenolic compounds, methylxanthines and antioxidant activity of cocoa mass and dark chocolate from cocoa cultivars resistant to "witch broom disease" and non resistant to the disease. The total phenolic compounds in cocoa mass did not vary among cultivars with values ranging from $23.95 \mathrm{mg} \mathrm{g}^{-1}$ to $25.03 \mathrm{mg} \mathrm{g}^{-1}$. Chocolates made from non resistant cultivars showed higher total phenolic compounds $\left(19.11 \mathrm{mg} \mathrm{g}^{-1}\right)$ than SR162 and PH16 with $16.08 \mathrm{mg} \mathrm{g}^{-1}$ and $15.46 \mathrm{mg} \mathrm{g}^{-1}$, respectively. Epicatechin had higher content than catechin and the levels of these two compounds were higher in SR162. There were significant differences among samples of cocoa mass analyzed for caffeine. Chocolate made from SR162 had the highest amount of monomeric compounds due to its high concentration of catechin and epicatechin. The chocolate sample with the highest antioxidant activity was the SR162, followed by non resistant blend and PH16, showing relationship between the antioxidant activity and monomeric phenolics content.
\end{abstract}

Index terms: Functional food, theobromine, caffeine, epicatechin, catechin.

\section{RESUMO}

A "vassoura bruxa" causada pelo fungo Moniliophthora perniciosa, é uma das doenças mais importantes do cacau na América Latina, provocando uma redução de cerca de $70 \%$ na produção das amêndoas na Bahia. Para tentar resolver o problema, muitos cultivares resistentes à enfermidade têm sido recomendados para os agricultores. Por outro lado, as características do chocolate são oriundas de várias substâncias, cuja formação depende da origem genética do fruto, do meio ambiente onde o cacau é cultivado e das operações de processamento. Assim, neste trabalho, objetivou-se determinar os compostos fenólicos monoméricos, metilxantinas e a atividade antioxidante em massa de cacau e chocolates provenientes de cultivares resistentes à "vassoura de bruxa" e não resistentes à doença. Os compostos fenólicos totais na massa de cacau não variou entre os cultivares com valores que variam entre $25,03 \mathrm{mg} \mathrm{g}^{-1}$ a $23,95 \mathrm{mg} \mathrm{g}^{-1}$. Chocolates feitos a partir de cultivares não resistentes à doença apresentaram maior teor de fenólicos totais $\left(19,11 \mathrm{mg} \mathrm{g}^{-1}\right)$ que os cultivares resistentes, SR162 e PH16 com 16,08mg.g $\mathrm{g}^{-1}$ e 15,46 mg.g $\mathrm{g}^{-1}$, respectivamente. Os conteúdos de epicatequina foram superiores aos de catequina em todos os cultivares. Houve diferenças significativas entre as amostras de massa de cacau analisadas para a cafeína. Chocolates produzidos a partir do cultivar SR162 apresentaram maior quantidade de compostos fenólicos e metilxantinas. A amostra de chocolate com a atividade antioxidante mais elevada é a SR162, seguida dos cultivares não resistentes e PH16, mostrando uma relação entre a atividade antioxidante e o conteúdo de compostos fenólicos monoméricos.

Termos para indexação: Alimentos funcionais, teobromina, cafeína, epicatequina, catequina.

(Received in january 1, 2013 and approved in march 15, 2013)

\section{INTRODUCTION}

The "witch broom disease" caused by the fungus called Moniliophthora perniciosa is one of the most important cocoa diseases in Latin America and Caribbean Islands causing huge economic losses. In southern Bahia, the mean productivity of cocoa has decreased around $70 \%$ since the disease emergence in 1989 (MANDARINO; GOMES, 2009). As a way to bypass the problem, many cultivars have been

\footnotetext{
1 Universidade Federal da Bahia/UFBA - Salvador - BA - Brasil

Universidade Federal da Bahia/UFBA - Departamento de Análises Bromatológicas, Faculdade de Farmácia - 40170-115 - Salvador - BA - Brasil ssoares.ssa@gmail.com

${ }^{3}$ Universidade Federal da Bahia/UFBA - Departamento de Análises Bromatológicas, Faculdade de Farmácia - Salvador - BA - Brasil
}

Ciênc. agrotec., Lavras, v. 37, n. 3, p. 244-250, maio/jun., 2013 
recommended by the Comissão Executiva do Plano da Lavoura Cacaueira (CEPLAC) to farmers in order to have new resistant crops with higher productivity.

On the other hand, in the last few years, researches have been intensified the aiming at finding fruits, vegetables, plants, agricultural and agro-industrial residues as sources of bioactive compounds (MARTINS et al., 2011). However, the lack of knowledge about the content of active ingredients and their molecular composition restrict their use as natural antioxidant sources. Thus, the screening of various food products, with beneficial health properties is very important (SHAHIDI et al., 1994).

The first human clinical study with chocolate was performed in 1996, when it was found that 35 grams of defatted cocoa decreased the LDL oxidation between 2 and 4 hours after ingestion. Since 1996, other 38 human studies involving the use of cocoa in different forms have been performed and can be summarized under three main headings: antioxidant properties, cardiovascular protection and anticarcinogenic action (RUSCONI; CONTI, 2010).

The chocolate flavour is composed of many compounds whose formation depends on the genetic background, environment where cocoa is grown and processing operations that begin on the farm (harvesting, fermenting and drying) and continue in the industries that process cocoa and chocolate (BRUNETTO et al., 2007). In addition, there are also internal factors in the beans that can affect the flavour, such as polyphenol content (NOORSOFFALINA et al., 2009), which are responsible for the astringency and contribute to bitterness (MISNAWI et al., 2004).

Cocoa bean is one of best known sources of dietary polyphenols, which comprises on average $12-18 \%$ of total weight on a dry basis. Generally, cocoa contains significant content of procyanidin monomers, as catechin and epicatechin, and other dimer to tetradecamer molecules (MENG et al., 2009). Methylxanthines, such as caffeine and theobromine, are another group of bioactive compounds found in cocoa beans. These alkaloids have a stimulating effect on the brain and some works connect the presence of these compounds in chocolates with some effects, such as addiction and blood pressure reduction (BRUINSMA; TAREN, 1999).

This work aimed at determining the monomeric phenolic compounds and methylxantines content as well as the antioxidant activity of the cocoa mass and the dark chocolate (70\% of cocoa) from cocoa cultivars resistant and on-resistant to "witch broom disease" (Moniliophthora perniciosa).

\section{MATERIALS AND METHODS}

Dark chocolates, containing $70 \%$ cocoa, made from cultivars resistant to "witch broom disease", "SR162" and "PH16", and a blend of non-resistant cultivars composed by Pará, Parazinho and Maranhão all of them belonging to Forastero group were used. These Forastero cultivars are grown from decades in Bahia State; considered a material of high productivity and high fruit quality; however, non-resistant to the disease.

The "PH16" is a cultivar originated from a selection performed in a commercial area. It has unknowing parents and the plant was originally identified in 1996 in a hybrid cocoa population (crosses between Amazônico group and Trinitario) from "Porto Híbrido" farm, São José da Vitória municipality, Bahia, Brazil.

The "SR162" is a cultivar derived from genetic mutation of the common cocoa (Alto Amazônico group) with white seeds. The name came from the farm where there were identified, "São Roque" farm in Itagibá, Bahia, Brazil.

\section{Preprocessing of cocoa beans}

The fermentation was carried out in $70 \mathrm{~cm} \times 70 \mathrm{~cm} \mathrm{x}$ $75 \mathrm{~cm}$ wooden boxes. A total mass of $400 \mathrm{Kg}$ in each box were processed. Turnings were performed for oxygenation and mixing of the mass 48 hours from the beginning of each fermentation and after decreasing temperature until the end of the process. After fermentation, seeds were dried in the sun-roof surfaces with mobile timber for 5 to 7 days up to $8.0 \%$ of moisture.

\section{Chocolate processing}

The fermented and dried beans were roasted in a circular roaster (Jaf Inox, Sao Paulo, Brazil) at $120^{\circ} \mathrm{C}$, for 2 hours. Then, the toasted beans were crushed and removed the peel and germ (cocoa nibs). The nibs were ground in a knife mill and refined sugar was added. The cocoa mass was refined in a five roll mill to yield optimal particle size for the chocolate. The refined mass was taken to conching held in horizontal shell (Jaf Inox, Sao Paulo, Brazil) $60^{\circ} \mathrm{C}$, for 48 hours. Commercial deodorized cocoa butter (Joanes Industrial S/A Chemicals and Plants) and commercial soy lecithin (Bunge Alimentos S/A) were added. The chocolate was carried out for tempering process in a shaking platform brand until reaching temperature of $42^{\circ} \mathrm{C}$ to form stable crystals of cocoa butter. The chocolate was molded in a polyethylene former, producing a $5 \mathrm{~g}$ bars. The chocolates were cooled, packaged and remained at $18^{\circ} \mathrm{C}$. 


\section{Extraction of phenolic compounds}

Methanolic extracts were obtained according to Fantozzi and Montedoro (1978). Ten grams of cocoa mass and chocolate were weight and defatted with petroleum ether, under shacking during 30 minutes for three times. From defatted samples, five grams were weight and $80 \%$ methanol in water (v/v) solution were added and stirring during one hour. After filtration, the methanolic extracts were stored in dark flask under nitrogen atmosphere at low temperature.

\section{Determination of total phenols}

The spectrophotometric method was used to determine the total phenolic content according to the method described by Gutfinger (1981) using FolinCiocalteu reagent. The phenolic content was calculated based on the catechin calibration curve.

\section{Determination of monomeric phenols and methylxanthines by HPLC}

The determination of monomeric phenolic compounds (galic acid, catechin, caffeic acid and epicatechin) and methylxantines (caffeine and theobromine) was performed according to the method described by Elwers et al. (2009). Ten microlitres of each sample solution was analyzed by HPLC system (Perkin Elmer Model Flexar) equipped with VI Flow injector, C 18 column (100mm x 4.6mm O.D.S.-2, $3 \mu$ ) and using the solvents (A): $2 \%$ acetic acid in water and (B): a mixture of acetonitrile, water and acetic acid (400:90:10 v/v/v). Elution was performed with a linear gradient showed in table 1 . The compounds were monitored by UV detection at $280 \mathrm{~nm}$ wavelength. The total run time was $20 \mathrm{~min}$ and the temperature was $26^{\circ} \mathrm{C}$. All standards used for quantitative determinations were from Sigma-Aldrich, St. Louis, MO.

Table 1 - HPLC gradient used for separation of phenolic compounds and methylxanthines in cocoa mass and chocolates.

\begin{tabular}{cccc}
\hline Time $(\mathrm{min})$ & Flow rate $\left(\mathrm{ml} \mathrm{min}^{-1}\right)$ & $\mathrm{A}(\%)$ & $\mathrm{B}(\%)$ \\
\hline 2 & 0.4 & 90 & 10 \\
3 & 0.3 & 88 & 12 \\
3 & 0.4 & 86 & 14 \\
2 & 0.4 & 84 & 16 \\
2 & 0.5 & 82 & 18 \\
10 & 0.5 & 90 & 10 \\
\hline
\end{tabular}

\section{Antioxidant Activity of Cocoa Mass and Chocolates Extracts}

The antioxidant activity of the extracts was determined using the DPPH(1,1-difenil-2-picrilidrazil) test as described by Vinson et al. (2001). For evaluating the antioxidant activity, the methanolic extracts at $2.5 \mathrm{mg} \mathrm{ml}^{-1}$ were submitted to the reaction with DPPH, in which $0.5 \mathrm{ml}$ of the sample was mixed with $4 \mathrm{~mL}$ of a $0.004 \%(\mathrm{~m} / \mathrm{v}) \mathrm{DPPH}$ solution. The radical DPPH reduction was measured through the continuous monitoring of the absorbance decline at $517 \mathrm{~nm}$ against ethanol in $4 \mathrm{ml}$ cuvettes using a UV spectrophotometer for $30 \mathrm{~min}$ at room temperature in the dark. The absorbance decrease of samples was calculated in comparison to the blank sample and expressed as percentage of the antioxidant activity. The antioxidant activity of each sample $\left(\mathrm{IC}_{50}\right)$ was then reported as the final concentration in $\mu \mathrm{g} \mathrm{ml}^{-1}$ of the extract present in the cuvette required for the initial DPPH concentration decrease to $50 \%$.

\section{Statistical analysis}

Data were subjected to analysis of variance (oneway ANOVA) using the Tukey test at 5\% significance for means comparison .

\section{RESULTS AND DISCUSSION}

The total phenolic content in cocoa mass did not vary among cultivars ranging from $23.95 \mathrm{mg} \mathrm{g}^{-1}$ to $25.03 \mathrm{mg} \mathrm{g}^{-1}$ and expressed as catechin equivalent (Table 2 ). When comparing these compounds in chocolate, non resistant cultivars of blend chocolate showed higher phenolic content than the other ones, SR162 and PH16. This is expected due to the fungal infection, since the synthesis of phenolic compounds is enhanced in the presence of phytopathogens (SOARES, 2002). When a plant is attacked by a potential pathogen, there is activation of the defense responses complex, with expression of various genes, resulting in synthesis and accumulation of secondary

Table 2 - Total phenolics $\left(\mathrm{mg} \mathrm{g}^{-1}\right)$ in cocoa mass and chocolates (mean \pm sd).

\begin{tabular}{ccc}
\hline & Cocoa mass & Chocolate \\
\hline Non resistant & $25.78 \pm 1.40^{\mathrm{a}^{*}}$ & $19.11 \pm 0.14^{\mathrm{a}}$ \\
SR162 & $25.03 \pm 0.76^{\mathrm{a}}$ & $16.08 \pm 0.79^{\mathrm{b}}$ \\
PH16 & $23.95 \pm 1.58^{\mathrm{a}}$ & $15.46 \pm 1.02^{\mathrm{b}}$ \\
\hline * Means with same letter in the columns are not significantly \\
different according to the ANOVA with Tukey test $(\mathrm{p}<0.05)$
\end{tabular}

Ciênc. agrotec., Lavras, v. 37, n. 3, p. 244-250, maio/jun., 2013 
metabolites such as phenolic compounds (SOUZA et al., 1999).

Another important point to be considered is the pre-processing (fermentation, drying and roasting) of cocoa, which according to some authors reduces the concentration of these kind of compounds (ADAMSON et al., 1999; STAHL et al., 2009). Furthermore, the concentration of phenolic compounds varies according to cultivar employed and also the type of chocolate produced (MILLER et al., 2006; PAYNE et al., 2010).

The results obtained in this work were lower than those found by Vinson et al. (2006) in USA, with $23.80 \mathrm{mg}$ $\mathrm{g}^{-1}$ of phenolics in dark chocolate and Cooper et al. (2008) in Europe that found $23.40 \mathrm{mg} \mathrm{g}^{-1}$, but on the other hand, Meng et al. (2009) found 5.78 $\mathrm{mg} \mathrm{g}^{-1}$ in Malaysia, which suggest that different regions with specific soil and climatic characteristics can result in fruits with their own characteristics for chocolate production.

The phenolic composition of cocoa mass samples is reported in table 3. Caffeic acid was the phenolic compound with lower content detected in the samples, showing no statistical differences between them. Gallic acid was not detected in the SR162 sample, but found in non resistant cocoa and $\mathrm{PH} 16$, also with no statistical difference between them. This acid is the basic constituent of hydrolysable tannins, being widely found in lignified plants. Besides the antioxidant potential, gallic acid is responsible for the astringent sensation in the mouth, which can promote different sensory characteristics to these cultivars. Epicatechin had higher content than catechin and, the SR162 showed higher values than the other cultivars, either for epicatechin or cathechin. Although no differences in total phenolic content had been observed among the three samples, the SR162 had higher content of monomeric phenols, thus having greater proportion of phenolic polymers, such as procyanidins in the other cultivars (PH16 and non resistant).

It is expected tccchat these facts contribute to chocolate flavour, since those compounds promote different sensory characteristics to the chocolates. The monomeric phenolic is responsible for the bitter taste and the polymeric forms for adstringency (AFOAKWA et al., 2008).

Concerning to methylxanthines in cocoa mass, there were significant differences among samples for caffeine. Cocoa mass from PH16 showed higher concentration, followed by the non resistant cocoa and the lowest concentration was found in SR162. No statistical difference $(\mathrm{p}<0.05)$ was found among samples for theobromine.

Nevertheless, changes can occur in polyphenols and methylxanthines content during chocolate production, mostly during refining and conching, where high temperatures are achieved and the air is present. However, knowledge of these changes is limited (WOLLGAST; ANKLAM, 2000).

As occurred in cocoa mass, in chocolates, caffeine contents showed statistically significant difference between samples, SR162 showed lower values than the other cultivars (Table 4). Theobromine levels were higher than caffeine ones and also the SR162 showed higher values than the other cultivars.

This fact is very important, considering the health aspects, since caffeine acts as stimulant and vasoconstrictor, while theobromine acts as vasodilator, reducing the blood pressure. Moreover, theobromine acts as muscle relaxant and diuretic (BRUINSMA; TAREN, 1999; VAN DEN BOGAARD et al., 2010).

Table 3 - Phenolic and methylxanthines composition in cocoa mass samples (mean \pm sd).

\begin{tabular}{lrcr}
\hline & Non resistant & SR162 & PH16 \\
\hline & & Phenolics compounds $\left(\boldsymbol{\mu g} \mathbf{g ~ g}^{-\mathbf{1}}\right)$ \\
Galic acid & $124.26 \pm 6.88^{\mathrm{a}^{*}}$ & - & $132.32 \pm 9.81^{\mathrm{a}}$ \\
Catechin & $1,095.44 \pm 23.73^{\mathrm{a}}$ & $1,734.45 \pm 33.40^{\mathrm{b}}$ & $949.90 \pm 11.92^{\mathrm{a}}$ \\
Caffeic acid & $24.8 \pm 17.54^{\mathrm{a}}$ & $34.44 \pm 6.39^{\mathrm{a}}$ & $43.63 \pm 5.85^{\mathrm{a}}$ \\
Epicatechin & $1,618.74 \pm 31.30^{\mathrm{a}}$ & $1,852.07 \pm 29.89^{\mathrm{b}}$ & $1,551.90 \pm 14.44^{\mathrm{a}}$ \\
& \multicolumn{4}{c}{${\text { Methylxanthines }\left(\boldsymbol{\mu g} \mathbf{g ~ g}^{-\mathbf{1}}\right)}$} \\
Caffeine & $1.98 \pm 0.01^{\mathrm{a}}$ & $1.01 \pm 0.20^{\mathrm{b}}$ & $3.02 \pm 0.20^{\mathrm{c}}$ \\
Theobromine & $6.57 \pm 0.03^{\mathrm{a}}$ & $7.23 \pm 1.32^{\mathrm{a}}$ & $6.67 \pm 0.30^{\mathrm{a}}$ \\
\hline
\end{tabular}

* Means with same letter in the rows are not significantly different by the ANOVA with Tukey test $(\mathrm{p}<0.05)$.

(-) Not Detected. 
Table 4 - Phenolic and methylxanthines composition in chocolate samples (mean \pm sd).

\begin{tabular}{lccc}
\hline & Non resistant & SR162 & PH16 \\
\hline & & Phenolic compounds $\left(\boldsymbol{\mu g} \mathbf{g ~ g}^{-1}\right)$ & \\
Galic acid & $30.03 \pm 0.33^{\mathrm{a}^{*}}$ & - & $14.83 \pm 10.20^{\mathrm{a}}$ \\
Catechin & $845.37 \pm 15.83^{\mathrm{a}}$ & $928.60 \pm 18.75^{\mathrm{a}}$ & $767.83 \pm 43.83^{\mathrm{a}}$ \\
Caffeic acid & - & - & $26.3 \pm 1.68$ \\
Epicatechin & $1,107.73 \pm 30.60^{\mathrm{a}}$ & $1,161.66 \pm 36.94^{\mathrm{a}}$ & $991.14 \pm 60.65^{\mathrm{a}}$ \\
& & Methylxanthines $^{\mathrm{a}} \boldsymbol{\mu \mathbf { g ~ g } ^ { - \mathbf { 1 } } )}$ & \\
Caffeine & $0.90 \pm 0.36^{\mathrm{a}}$ & $0.62 \pm 0.07^{\mathrm{b}}$ & $0.84 \pm 0.05^{\mathrm{a}}$ \\
Theobromine & $2.21 \pm 0.11^{\mathrm{a}}$ & $3.00 \pm 0.27^{\mathrm{b}}$ & $2.01 \pm 0.10^{\mathrm{a}}$ \\
\hline
\end{tabular}

* Means with same letter in the rows are not significantly different according to the ANOVA with Tukey test ( $<<0.05$ ).

(-) Not Detected.

Concerning phenolic compounds in chocolate, their content was reduced for all samples, since other ingredients are combined in their production, reducing the phenolic content. Nevertheless, in chocolate made from SR162, caffeic acid and gallic acid were not detected, though this sample had the highest content of monomeric compounds $(2,090.26$ $\mu \mathrm{g} \cdot \mathrm{g}^{-1}$ ), which represents $13.0 \%$ of total phenolics. In chocolate made with non resistant cultivars, caffeic acid was not detected and the total monomers identified was $1,983.13 \mu \mathrm{g} . \mathrm{g}^{-1}$ representing $10.4 \%$ of total phenolic compounds, while the chocolate from the PH16 variety had all monomers detected, with a total of $1,800,10 \mu \mathrm{g} \cdot \mathrm{g}^{-1}$ : equivalent to $11.64 \%$ of total phenolics for chocolate.

SR162 showed higher levels of monomeric phenolics in chocolate, which can help its flavor composition, since the phenolic compounds are responsible for the bitter characteristic. Besides, the healthy aspects of these compounds should be considered, since the monomeric form of phenolic compounds is ready to be absorbed and used by human body as exogenous antioxidants (RICHELLE et al., 1999; HOLT; LAZARUS; SULLARDS, 2002).

The assay with DPPH (the stable radical 2,2diphenyl-1-picryl hydrazyl) has been frequently used to assess the ability of natural antioxidants to "mop up" free radicals (ROESLER et al., 2007). The capacity of the different extracts from chocolates of reducing free radicals was expressed as the extract final concentration necessary to inhibit $50 \%$ of the DPPH radical oxidation, which represents $\mathrm{IC}_{50}$ (Table 5).

The chocolate sample with the highest antioxidant activity is SR162, followed by the non resistant and PH16, with the lowest antioxidant activity among the three varieties. The DPPH free radical scavenging activity is strongly correlated with the total flavonoid content (ABU BAKAR et al., 2009). Indeed, according to Oliveira et al. (2011), the relationship between the antioxidant activity of cocoa extracts and the concentration of total phenols seems to be quite significant, since the extracts with the highest concentrations of monomeric phenols are those with highest antioxidant activity. Besides, the SR162 extract showed the highest content of catechin and epicathechin, flavonoids with excellent antioxidant activity. However, the result did not show a relationship between the antioxidant activity and the total phenolics, since the extract with the highest concentration of total phenolics (non resistant) had the second highest antioxidant activity. It can be explained by the flavonoid-flavonoid interaction that reduces or increases the total antioxidant activity (HIDALGO; SÁNCHEZMORENO; PASCUAL-TERESA, 2010) and probably the higher levels of polymeric phenols. Therefore, epicatechin and catechin seem to be the main compounds responsible for the antioxidant activity of chocolate extract. These results suggest a major correlation between antioxidant capacity and monomeric phenolic content instead of the total phenolic content (MACIEL et al., 2011).

Table 5 - Antioxidant activity $\left(\mu \mathrm{g} \mathrm{ml}^{-1}\right.$ ) of chocolates produced from non resistant and resistant cultivars of cocoa to "witch broom disease" in Brazil.

\begin{tabular}{cc}
\hline Sample & $\mathrm{IC}_{50}\left(\mu \mathrm{g} \mathrm{ml}^{-1}\right)^{*}$ \\
\hline Non resistant & $19.20 \pm 0.55^{\mathrm{b}^{* *}}$ \\
SR162 & $15.15 \pm 1.88^{\mathrm{c}}$ \\
PH16 & $20.47 \pm 1.86^{\mathrm{a}}$ \\
\hline
\end{tabular}

* The $\mathrm{IC}_{50}$ value was obtained by using three replicates from four different extract concentrations. This covered the range from low to high inhibition of the DPPH radical.

** Means with same letter in the rows are not significantly different according to ANOVA with Tukey test ( $p<0.05)$. 


\section{CONCLUSIONS}

The chocolates from SR162 cultivar, which is resistant to "witches' broom disease", showed higher antioxidant activity as well as higher concentration of monomeric phenolic compounds (catechin and epicatechin) than the other cultivars studied. Besides, the SR162 has higher levels of theobromine and lower caffeine. These results provide a new perspective of using the SR 162 and other new cultivars resistant to "witches' broom disease" to produce chocolate with desirable sensory attributes, and great potential for use as functional food.

\section{ACKNOWLEDGEMENTS}

To FAPESB (Fundação de Amparo à Pesquisa do Estado da Bahia) for the scholarship and the CNPq (Conselho Nacional de Desenvolvimento Científico e Tecnológico) for the financial support.

\section{REFERENCES}

ABU BAKAR, M.F. et al. Phytochemicals and antioxidant activity of different parts of bambangan (Mangifera pajang) and tarap (Artocarpus odoratissimus). Food Chemistry, Barking, v.113, n.2, p.479-83, 2009.

ADAMSON, GE. et al. HPLC Method for the quantification of procyanidins in cocoa and chocolate samples and correlation to total antioxidant capacity.

Journal of Agricultural and Food Chemistry, Washington, v.47, n.10, p.4184-8, 1999.

AFOAKWA; E.O. et al. Flavor formation and character in cocoa and chocolate: A critical review. Critical Reviews in Food Science and Nutrition, Boca Raton, v.48, n.9, p.840-57, 2008.

BRUINSMA, K; TAREN, D.L. Chocolate: food or drug? Journal of the American Dietetic Association, Chicago, v.10, n.10, p.1249-56, 1999.

BRUNETTO, M.R. et al. Determination of theobromine, theophylline and caffeine in cocoa samples by a high-performance liquid chromatographic method with on-line sample cleanup in a switching-column system. Food Chemistry. Barking, v.100,n.2, p.459-67, 2007.

COOPER, K.A. et al. Predictive relationship between polyphenol and nonfat cocoa solids content of chocolate. Journal of Agricultural and Food Chemistry, Washington, v.56, n.1, p.260-5, 2008.

ELWERS, S. et al. Differences between the content of phenolic compounds in Criollo, Forastero and Trinitario cocoa seed (Theobroma cacao L.). European

Food Research and Technology, Berlin, v.229, n.6, p.93748, 2009.

FANTOZZI, P. ; MONTEDORO, G. Dosage dês composés phénoliques dans drupes d'olives récoltés à differents stades de maturation. Industrie Alimentaire et Agricole, Paris, v.17, n.12, p.1335-9, 1978.

GUTFINGER, T. Polyphenols in olive oils. Journal of the American Oil Chemists Society, Champaign, v.58, n.11, p.966-8, 1981.

HIDALGO, M.; SÁNCHEZ-MORENO, C.; PASCUALTERESA, S. Flavonoid-flavonoid interaction and its effect on their antioxidant activity. Food Chemistry, Barking, v.121, n.3, p.691-6, 2010.

HOLT, R.R.; LAZARUS, S.A.; SULLARDS, M. Procyanidin dimer B2 (epicatechin-(4 - 8)epicatechin) in human plasma after the consumption of a flavanol-rich cocoa. American Journal of Clinical Nutrition, Bethesda, v.76, n.4, p.798-804, 2002.

MACIEL, L.F. et al. Antioxidant activity, total phenolic compounds and flavonoids of mangoes coming from biodynamic, organic and conventional cultivations in three maturation stages. British Food Journal, Bradford, v.113, n.9, p.1103-13, 2011.

MANDARINO, E. P.; SENA GOMES, A. R. Produtividade do cacaueiro (Theobroma cacau L.) cultivados em blocos monoclonais, no sul da Bahia, Brasil. Ilhéus, CEPLAC/CEPEC. Boletim Técnicon ${ }^{\circ}$ 197, 2009, 32p.

MARTINS, S. et al. Bioactive phenolic compounds: Production and extraction by solid-state fermentation. A review. Biotechnology Advances, New York, v.29, n.3, p.365-73, 2011.

MENG, C.C. et al. Phenolic and theobromine contents of commercial dark, milk and white chocolates on the Malaysian market. Molecules, Berlin, v.14, n.1, p.200-9, 2009. 
MILLER, KB. et al. Antioxidant activity and polyphenol and procyanidin contents of selected commercially available cocoa containing and chocolate products in the United States. Journal of Agricultural and Food Chemistry, Washington, v.54, n.11, p.4062-8, 2006.

MISNAWI; et al. Sensory properties of cocoa liquor as affect by polyphenol concentration and duration of roasting. Food Quality and Preference, Barking, v.15, n.5, p.403-9, 2004.

NOOR-SOFFALINA, S.S. et al. Effect of polyphenol and $\mathrm{pH}$ on cocoa Maillard-related flavor precursors in a lipidic model system. International Journal of Food Science \& Technology, Oxford, v.44, n.1, p.168-80, 2009.

OLIVEIRA, C.S. et al. Phenolic compounds, flavonoids and antioxidant activity in different cocoa samples from organic and conventional cultivation. British Food Journal, Bradford, v.113, n.9, p.1094-102, 2011.

PAYNE, MJ. et al. Impact of fermentation, drying, roasting, and dutch processing on epicatechin and catechin content of cacao beans and cocoa ingredients. Journal of Agricultural and Food Chemistry, Washington, v. 58, n.19, p.10518-27, 2010.

RICHELLE, M. et al. Plasma kinetics in man of epicatechin from black chocolate. European Journal of Clinical Nutrition, London, v.53, n.1, p.22-6, 1999.

ROESLER, R. et al. Atividade Antioxidante de frutas do cerrado. Ciência e Tecnologia de Alimentos, Campinas, v.27, n.1, p.53-60, 2007.

RUSCONI, M.; CONTI, A. Theobroma cacao L., the Food of the Gods: A scientific approach beyond myths and claims. Pharmacological Research, London, v.61, n.1, p.05-13, 2010.

SHAHIDI, F.; WANASUNDRA, U.N.; AMAROWICH, R. Natural antioxidant from low pungency mustard flour.
Food Research International, Essex, v.27, n.5, p.489-93, 1994.

SOARES, S.E. Phenolic acids as antioxidants. Revista de Nutrição, Campinas, v.15, n.1, p.71-81, 2002.

SOUZA, A.L.B. et al. Resistência pós-colheita do pêssego (Prunus persica cv. biuti) a Monilinia fructicola: indução de respostas bioquímicas pela aplicação do $\mathrm{CaCl}_{2}$ no local da injúria. Ciência e Agrotecnologia, Lavras, v.23, n.4, p.864-74, 1999.

STAHL, LA. et al. The preservation of cocoa antioxidant activity, total polyphenols, flavan-3-ols and procyanidin content in cooked and baked foods prepared with cocoa powder. Journal of Food Science, Champaign, v.74, n.6, p.456-461, 2009.

VAN DEN BOGAARD, B. et al. Effects on peripheral and central blood pressure of cocoa with natural or high dose theobromine: a ramdomized, double-blind crossover trial. Hypertension, Dallas, v.56, n.5, p.839-46, 2010.

VINSON, J.A. et al. Chocolate is a powerful ex vivo and in vivo antioxidant, an anti-atherosclerotic agent in an animal model, and significant contributor to antioxidants in European and American diets. Journal of Agricultural and Food Chemistry, Washington, v.54, n.21, p.8071-6, 2006.

VINSON, J.A. et al. Phenol antioxidant quantity and quality in foods: Fruits. Journal of Agricultural and Food Chemistry, Washington, v.49, n.11, p.5315-21, 2001.

WOLLGAST, J.; ANKLAM, E. Review on polyphenols in Theobroma cacao: changes in composition during the manufacture of chocolate and methodology for identification and quantification. Food Research International, Essex, v.33, n.6, p.423-47, 2000.

Ciênc. agrotec., Lavras, v. 37, n. 3, p. 244-250, maio/jun., 2013 